\title{
STUDI PARAMETER FISIKA KIMIA AIR UNTUK KERAMBA JARING APUNG DI KECAMATAN SIRAH PULAU PADANG KABUPATEN OGAN KOMERING ILIR PROVINSI SUMATERA SELATAN
}

\author{
Study On Water Physical-Chemical Parameters for Floating Net Cage Sirah Pulau Padang \\ Ogan Komering Ilir District of South Sumatra Province
}

\author{
Rangga Bayu Kusuma Haris ${ }^{1)}$ dan Indah Anggraini Yusanti ${ }^{2)}$ \\ ${ }^{1)}$ Budidaya Perikanan Fakultas Perikanan Universitas PGRI Palembang \\ ${ }^{2)}$ Ilmu Perikanan Fakultas Perikanan Universitas PGRI Palembang \\ Email: rangga.undip@yahoo.com
}

\begin{abstract}
Abstrak
Penelitian ini bertujuan untuk menganalisis parameter fisika-kimia yang meliputi suhu, pH, DO, kecerahan, amoniak, nitrat, fosfor, $\mathrm{CO}_{2}$, Arus air, Kedalaman, Kecerahan dan material dasar. Dari hasil penelitian Analisis Kesesuaian Lahan Keramba Jaring Apung Di Sungai Komering Desa Serdang Menang Kabupaten OKI Sumatera Selatan bahwa untuk Stasiun 1, Stasiun 2, dan Stasiun 3 dengan nilai $48 \%$ dengan keterangan kelayakan baik. Dari hasil pengukuran parameter kualitas air didapat pH kisaran 6.6 6.7, suhu berkisar $24 ., 53-26.93^{\circ} \mathrm{C}$, DO $3.93-4.36 \mathrm{mg} / \mathrm{l}$, ammonia $0.78-0,16 \mathrm{mg} / \mathrm{l}$, kecerahan perairan berkisar $34.67-43.33 \mathrm{~cm}, \mathrm{CO}_{2} 4.53-5.03 \mathrm{mg} / \mathrm{l}$, kedalaman $2.36-2.47 \mathrm{~m}$, kecepatan arus $0.38-0.44$ $\mathrm{m} / \mathrm{s}$, nitrat $0.37-0.439 \mathrm{mg} / \mathrm{l}$, fosfat $0.009-0.225 \mathrm{mg} / \mathrm{l}$ dan subtrat dasar perairan adalah lumpur.
\end{abstract}

Kata Kunci: Parameter Fisika dan Kimia, Keramba Jaring Apung

\begin{abstract}
This study aims to analyze physical-chemical parameters which include temperature, $p H$, DO, brightness, ammonia, nitrate, phosphorus, $\mathrm{CO}_{2}$, water flow, depth, brightness and basic material. From the results of the study of Suitability Analysis of Floating Net Cages in the Komering River, Serdang Menang Village, OKI Regency, South Sumatra that for Station 1, Station 2, and Station 3 with a value of $48 \%$ with good feasibility information. From the results of measurements of water quality parameters obtained a pH range of 6.6 - 6.7, temperatures ranging from $2453-26.93^{\circ} \mathrm{C}, \mathrm{DO} 3.93$ - $4.36 \mathrm{mg} / \mathrm{l}$, ammonia 0.78 - 0.16 $\mathrm{mg} /$, water brightness ranging from $34.67-43.33 \mathrm{~cm}, \mathrm{CO}_{2} 4.53-5.03 \mathrm{mg} / \mathrm{l}$, depth $2.36-2.47 \mathrm{~m}$, current speed $0.38-0.44 \mathrm{~m} / \mathrm{s}$, nitrate $0.37-0.439 \mathrm{mg} / \mathrm{l}$, phosphate $0.009-0.225 \mathrm{mg} / \mathrm{l}$ and the bottom substrate of the water is mud.
\end{abstract}

Keywords: Physical and Chemical Parameters, Floating Net Cages 


\section{PENDAhUluAN}

Potensi sumberdaya perikanan budidaya pada perairan umum daratan merupakan peluang besar untuk dikembangkan, hal ni didukung ketersediaan lahan yang masih memadai untuk pengembangan kolam budidaya ikan serta keberadaan perairan umum (sungai, waduk, situ) untuk pengembangan budidaya keramba (Rizal, 2013). Menurut Effendi (2003), adanya kegiatan perikanan tersebut akan memberikan dampak perubahan kualitas perairan akibat masukan bahan yang akan menimbulkan pencemaran berupa limbah atau polutan organic dan anorganik ke perairan. Jumlah penduduk yang begitu tinggi menyebabkan adanya tuntutan pendayagunaan sumberdaya yang terus meningkat dari waktu kewaktu. Kondisi ini memacu terjadinya pengelolaan sumberdaya secara eksploitatif dan keseimbangan lingkungan bisa terganggu. Oleh sebab itu pemanfaatan sumberdaya perlu mempertimbangkan kemampuan daya dukung wilayah setempat (Haris, 2014). Menurut Hasnawi dan Mustafa (2010), perbedaan kombinasi penyusun lingkungan fisik lahan akan memberikan perbedaan lahan dan cara pengelolaan lahan yang berbeda.

Sungai komering banyak dimanfaatkan masyarakat untuk budidaya ikan dalam keramba terutama di Kecamatan Sirah Pulau Padang. Dengan semakin berkembangnya kegiatan budidaya ikan dalam keramba dan adanya tuntutan peningkatan produksi, tentu akan menimbulkan pengaruh terhadap mutu lingkungan dan kualitas perairan. Pemeliharaan ikan dalam keramba di sungai Komering di Kecamatan Sirah Pulau Padang jika tidak dilaksanakan dengan prinsip sustainability akan menimbulkan dampak penurunan mutu perairan yang digunakan dan tidak dapat dimanfaatkan secara berkelanjutan. Perubahan kualitas perairan dapat diketahui dari indikator kimia, fisika, maupun biologis. Indikator kimiawi dapat diketahui melalui penilaian kualitas perairan yang meliputi antara lain
pH-air, oksigen terlarut, karbondioksida. Indikator fisika dapat diketahui melalui parameter suhu air, kecerahan dan arus air (Samuel dan Adjie, 2008).

\section{METODE PENELITIAN}

\section{Waktu dan Tempat}

Penelitian ini dilakukan di sekitar perairan desa Ulak Jermun, Desa Mangun Jaya dan Desa Terusan Menang kecamatan SirahPulau Padang Kabupaten Ogan Komering Ilir Sumatera Selatan yang banyak budidaya ikan dalam keramba. Pengambilan contoh dilakukan pada bulan Juli sampai dengan Agustus 2018.

\section{Analisis Data}

Pengamatan secara langsung meliputi: suhu, kecerahan, kedalaman, kecepatan arus, kandungan oksigen, subtrat dasar perairan, dan $\mathrm{pH}$. Sedangkan parameter ammonia, nitrat, $\mathrm{CO}_{2}$, dan fosfat. Dalam penelitian ini yang menjadi sumber data sekunder adalah literatur, artikel, jurnal serta situs di internet yang berkenaan dengan penelitian yang dilakukan.

\section{HASIL DAN PEMBAHASAN}

Hasil pengamatan kondisi perairan di sungai Komering pada saat surut dan pasang menunjukan nilai yang berfluktuasi. Pengamatan dilakukan sebanyak tiga kali dengan titik stasiun yang telah ditentukan yaitu area Desa Ulak Jermun (stasiun 1), DesaTerusanMenang (stasiun 2), dan Desa Mangun Jaya (stasiun 3). Perubahan kualitas air dipengaruhi oleh perubahan muka air. Dalam proses tersebut juga akan terjadi proses pelarutan mineral-mineral dari tanah yang sebelumnya kering, diikuti oleh proses pembusukan tumbuh-tumbuhan yang hidup di lahan surutan tersebut. Beberapa parameter kualitas air seperti suhu, $\mathrm{pH}$, kecerahan, kedalaman, kecepatan arus, $\mathrm{DO}, \mathrm{CO}_{2}, \mathrm{NH}_{3}, \mathrm{NO}_{3}$, dan fosfat menunjukkan perubahan sebagai akibat dari perubahan muka air.

Tabel 1. Hasil Pengukuran Kualitas Air pada 3 Stasiun

\begin{tabular}{lccc}
\hline \multicolumn{1}{c}{ Parameter } & $\begin{array}{c}\text { Stasiun 1 } \\
\text { Desa Ulak Jermun }\end{array}$ & $\begin{array}{c}\text { Stasiun 2 } \\
\text { Desa Terusan Menang }\end{array}$ & $\begin{array}{c}\text { Stasiun 3 } \\
\text { Desa Mangun Jaya }\end{array}$ \\
pH & 6.7 & 6.6 & 6.6 \\
Suhu $\left({ }^{0} \mathrm{C}\right)$ & 26.93 & 25.03 & 24.53 \\
DO $(\mathrm{mg} / \mathrm{l})$ & 3.93 & 4.27 & 4.36 \\
Kecerahan $(\mathrm{cm})$ & 42.67 & 43.33 & 34.67 \\
COD $(\mathrm{mg} / \mathrm{l})$ & 4.83 & 4.53 & 5.03 \\
Kedalaman $(\mathrm{m})$ & 2.41 & 2.26 & 2.47 \\
Kecepatan Arus $(\mathrm{m} / \mathrm{s})$ & 0.41 & 0.38 & 0.44 \\
Ammonia $\left(\mathrm{NH}_{3}\right)(\mathrm{mg} / \mathrm{l})$ & 0.0813 & 0.078 & 0.16 \\
Nitrat $(\mathrm{NO})(\mathrm{mg} / \mathrm{l})$ & 0,439 & 0.38 & 0.37 \\
Fosfat $\left(\mathrm{mg}_{3}\right)$ & 0.225 & 0.009 & 0.011 \\
Subtrat Dasar Perairan & Lumpur & Lumpur & Lumpur \\
\hline
\end{tabular}




\section{Derajat Keasaman (pH)}

Hasil pengukuran $\mathrm{pH}$ pengambilan sampel pada stasiun 1, 2 dan 3 berkisar 6.6 - 6.7 secara umum nilai $\mathrm{pH}$ masih normal. Pada $\mathrm{pH}$ rendah (keasaman tinggi) kandungan oksigen terlarut akan berkurang. Akibatnya, konsumsi oksigen menurun, aktivitas pernafasan naik dan selera makan akan berkurang. Pengaruh perairan asam ( $\mathrm{pH}$ rendah) akan kurang produktif untuk budidaya system KJA karena pertumbuhan ikan akan terhambat dan ikan rentan terkena bakteri dan parasit, bahkan bisa terjadinya kematian pada ikan (Effendi, 2003).

\section{Suhu}

Data pengukuran suhu air di Desa Ulak Jermun (stasiun 1), Desa Terusan Menang (stasiun 2), dan Desa Mangun Jaya (stasiun 3) pada pengambilan sampel kualitas air berkisar 24.53 $26.93{ }^{\circ} \mathrm{C}$. Menurut Hutabarat (2010) bahwa tingginya suhu disuatu perairan bisa disebabkan oleh tingginya cahaya matahari dan adanya pencampuran air, serta oleh faktor aktifitas yang ada diperairan tersebut. Suhu yang didapat dari hasil penelitian berkisar antara $24.53-26.93^{\circ} \mathrm{C}$ dan termasuk kedalam suhu normal yang dibutuhkan ikan untuk dapat berkembang dan bertahan hidup.

\section{Oksigen Terlarut (DO)}

DO (Dissolved Oxygen) atau oksigen terlarut merupakan zat yang paling penting dalam system kehidupan di perairan karena berperan penting dalam proses metabolism serta respirasi. Dari penelitian yang dilakukan, didapati oksigen terlarut di Desa Ulak Jermun (stasiun 1), DesaTerusan Menang (stasiun 2), dan Desa Mangun Jaya (stasiun 3) berkisar antara 3.93 - 4.36 $\mathrm{mg} / \mathrm{L}$ sehingga dapat disimpulkan jika oksigen terlarut di perairan tersebut dapat mendukung kegiatan KJA. DO dan suhu sangat berkaitan, semakin tinggi suhu maka DO akan semakin rendah. Menurut Sastrawijaya (2000) menyatakan bahwa kehidupan organism akuatik berjalan dengan baik apabila kandungan oksigen terlarutnya minimal 5 mg/l. Mundeng, dkk., (2013) biota air membutuhkan oksigen guna pembakaran bahan bakarnya (makanan) untuk menghasilkan aktifitas, seperti aktifitas berenang, pertumbuhan, reproduksi, dan sebaliknya.

\section{Kecerahan}

Kecerahan adalah suatu kondisi yang menunjukkan kemampuan cahaya untuk menembus lapisan air pada kedalaman tertentu. Kecerahan perairan sangat dipengaruhi oleh keberadaan padatan tersuspensi, zat - zat terlarut, partikel partikel dan warna air. Tingkat kecerahan memiliki kaitan erat dengan fotosintesis. Kecerahan berperan dalam menyediakan sinar matahari yang diperlukan oleh tumbuhan air dan fitoplankton dalam melakukan fotosintesis. Menurut Sumich (1992) dalam Asmara (2005) bahwa semakin dalam secchidisk semakin dalam penetrasi cahaya kedalam air, yang selanjutnya akan meningkatkan ketebalan lapisan air yang produktif. Tebalnya lapisan air yang produktif memungkinkan terjadinya pemanfaatan unsur hara secara kontinyu oleh produsen primer. Hasil pengamatan kecerahan pada pengambilan sampel saat air di stasiun 1, 2 dan 3 berkisar 34.67 - $43.33 \mathrm{~cm}$. Dari hasil pengamatan kecerahan pada Sungai Komering di Desa Ulak Jermun (stasiun 1), Desa Terusan Menang (stasiun 2), dan Desa Mangun Jaya (stasiun 3) secara umum tingkat kecerahan tersebut baik untuk pengembangan budidaya system KJA.

\section{Karbondioksida $\left(\mathrm{CO}_{2}\right)$}

Ketersediaan karbondioksida terlarut dalam air dapat bersumber dari air tanah, dekomposisi zat organik, respirasi organisme air, senyawa kimia dalam air maupun dari udara namun dalam jumlah yang sedikit. Hasil pengukuran $\mathrm{CO}_{2}$ pada pengambilan sampel $6.99 \mathrm{mg} / \mathrm{L} \mathrm{s} / \mathrm{d} \quad 7.03 \mathrm{mg} / \mathrm{L}$, terjadi peningkatan. Menurut Ellis dalam Boyd (1979), kandungan karbondioksida yang baik untuk menunjang kehidupan ikan adalah kurang dari 5,0 $\mathrm{mg} / \mathrm{l}$ dan ikan dapat mentolerir kandungan karbondioksida lebih dari $10 \mathrm{mg} / \mathrm{l}$ apabila kandungan oksigennya tinggi. Dari hasil pengamatan untuk karbondioksida $\left(\mathrm{CO}_{2}\right)$ di Sungai Komering desa Serdang Menang masih sesuai untuk budidaya perikanan system KJA dikarenakan tingginya karbondioksida yang terlarut dalam perairan tersebut, sedangkan oksigen terlarut hasil penelitian ini rendah yang merupakan keterbalikan dari hasil $\mathrm{CO}_{2}$ yang didapat.

Apabila karbondioksida $\left(\mathrm{CO}_{2}\right)$ yang dihasilkan dari respirasi makin banyak, reaksi bergerak kekanan dan secara bertahap melepaskan ion $\mathrm{H}^{+}$yang menyebabkan $\mathrm{pH}$ air turun dan reaksi sebaliknya $\mathrm{pH}$ air akan naik. Jumlah $\mathrm{CO}_{2}$ yang meningkat akan menekan aktifitas pernafasan ikan dan menghambat peningkatan oksigen oleh hemoglobin sehingga menjadi sumber stress bagi ikan. Ketersediaan karbondioksida adalah sumber utama untuk fotosintesis dan pada banyak cara menunjukkan keterbalikan dengan oksigen. Semakin menipisnya intensitas cahaya matahari, kandungan karbondioksida dalam air semakin besar. Sedangkan semakin banyaknya intensitas cahaya matahari, kandungan karbondioksida menipis kembali. Meskipun suhu dan $\mathrm{pH}$ merupakan faktor dalam regulasi konsentrasi oksigen dan karbondioksida, tetapi hal ini juga tergantung pada fotosintesis tanaman, respirasi dari semua organisme, aerasi air, keberadaan gas-gas lainnya dan oksidasi kimia yang mungkin terjadi.

\section{Kedalaman Air Sungai.}

Kedalaman lokasi KJA yang dipilih tidak boleh terlalu dangkal dan terlalu dalam. Hasil rata- 
rata pengukuran kedalaman pada pengambilan sampel berkisar antara $2.26 \mathrm{~m}-2.47 \mathrm{~m}$. Dalam WWF-Indonesia (Irwan dkk, 2015), ketinggian air pada saat kemarau atau surut minimal $1 \mathrm{~m}$ untuk KJT sedangkan untuk KJA jarak minimal antara dasar sungai/danau/waduk dengan dasar waring/jaring adalah $1 \mathrm{~m}$, sehingga didapat kedalaman untuk pengembangan budidaya perikanan air tawar seperti ikan patin masih bisa dilakukan di Desa Ulak Jermun (stasiun 1), Desa Terusan Menang (stasiun 2), dan Desa Mangun Jaya (stasiun 3). Menurut Sari (2011) menyatakan bahwa pada perairan dengan kedalaman terlalu dekat dengan dasar sehingga rentan terhadap penumpukan kotoran dari sisa pakan dan hasil metabolism ikan. Semakin dalam dasar permukaan air di kolam atau perairan tersebut, maka semakin luas ruang gerak ikan. Salah satu pertimbangan dalam menentukan kedalaman suatu kolam atau perairan, yaitu kemampuan sinar matahari untuk menembus ke dasar kolam atau suatu perairan (Susanto, 1986).

\section{Kecepatan Arus Sungai}

Hasil rata - rata pengukuran kecepatan arus pada pengambilan sampel saat air sungai surut dan pasang berkisar $0,38-0,44 \mathrm{~m} / \mathrm{s}$. Hal ini menunjukan bahwa kecepatan arus di lokasi penelitian relatif kencang, sebagaimana dalam WWF-Indonesia (Irwan dkk, 2015), penempatan KJA sebaiknya ditempatkan diperairan dengan pergerakan air cukup baik, kecepatan arus berkisar 0,5 m/menit untuk KJT dan untuk KJA berkisar 1 $\mathrm{m} /$ menit, sehingga untuk pengembangan budidaya perikanan system KJA layak untuk dilakukan di Desa Ulak Jermun (stasiun 1), Desa Terusan Menang (stasiun 2), dan Desa Mangun Jaya (stasiun 3). Menurut Effendi (2003) bahwa perairan lotik dicirikan oleh arus yang searah dan relatif kencang, dengan kecepatan arus berkisar antara $0,1-1,0 \mathrm{~m} /$ detik, serta sangat dipengaruhi oleh waktu, iklim, dan pola drainase. Kecepatan arus mempunyai pengaruh yang besar terhadap distribusi atau penyebaran organisme termasuk benthos. Selain itu kecepatan arus merupakan sarana transport yang baik untuk makanan maupun oksigen bagi organisme.

Menurut Odum (1996) yang menjadi acuan oleh Johan dan Ediwarman (2011) yang mengatakan bahwa kecepatan arus di sungai tergantung pada kemiringan, kekasaran, kedalaman dan kelebaran dasar perairan. arus berperan dalam sirkulasi air dan distribusi bahan terlarut maupun oksigen. Hal ini sesuai dengan pernyataan Affan (2012) yang menyatakan bahwa arus sangat berperan dalam sirkulasi air, selain pembawa bahan terlarut dan tersuspensi, arus juga mempengaruhi jumlah kelarutan oksigen dalam air. Di samping itu berhubungan dengan KJA, kekuatan arus dapat mengurangi organism penempel (fouling) pada jarring sehingga desain dan konstruksi keramba harus disesuaikan dengan kecepatan arus.

\section{Ammonia $\left(\mathrm{NH}_{3}\right)$}

Amonia merupakan parameter penting dalam budidaya perikanan system KJA karena dapat dianggap sebagai satu racun paling mematikan dalam kegiatan budidaya. Amonia merupakan produk akhir metabolisme nitrogen yang bersifat racun. Kandungan amoniak pada perairan sungai Komering di Desa Ulak Jermun (stasiun 1), Desa Terusan Menang (stasiun 2), dan Desa Mangun Jaya (stasiun 3). berkisar antara $0.078-0.16 \mathrm{mg} / \mathrm{L}$. Ammonia $\left(\mathrm{NH}_{3}\right)$ dalam air berasal dari bahan-bahan organik dan pengeluaran hasil metabolisme ikan melalui ginjal dan jaringan insang. Kemudian ammonia dalam keramba, tambak atau perairan dapat pula terbentuk sebagai hasil proses dekomposisi protein yang berasal dari sisa pakan atau plankton yang mati. Bila proses pembusukan (nitrifikasi) tidak berlangsung lancar maka terjadi pembusukan $\mathrm{NH}_{3}$ sampai pada konsentrasi yang membahayakan ikan. Menurut Boyd (1983), kandungan amoniak sudah dapat bersifat racun pada konsentrasi 0,6 - 2,0 mg/L. Daya racun amoniak akan meningkat sebanding dengan meningkatnya $\mathrm{pH}$ dan suhu.

Effendi (2003) dalam Slamet, dkk.(2013) mengemukakan bahwa ammonia dapat berasal dari limbah budidaya perikanan yang berupa feses dan pakan yang tidak dimakan yang terlepas ke lingkungan perairan. Amonia bebas yang tidak terionisasi bersifat toksik terhadap biota dan toksisitas tersebut akan meningkat jika terjadi penurunan kadar oksigen terlarut. Hal ini juga didukung oleh Beveridge (1996) yang diacu oleh Ervinia (2011) menyebutkan bahwa pakan ikan yang terbuang keperairan banyak mengandung nitrogen. Jumlah penambahan nutrient kebadan air dari keramba jarring apung tergantung pada densitas ikan dalam keramba. Hasil ekskres iikan akan disebarkan kekolom air oleh arus, sedangkan padatan (pakan yang tidak termakan dan feses) akan jatuh kebawah atau dasar perairan.

\section{Nitrat $\left(\mathrm{NO}_{3}\right)$}

Hasil pengamatan parameter nitrat pada stasiun 1, 2 dan 3 pengambilan sampel berkisar 0.37 - $0.439 \mathrm{mg} / \mathrm{L} . \mathrm{Chu}$ dalam Wardoyo (1982) mengemukakan bahwa kisaran kadar nitrat 0,3-0,5 $\mathrm{mg} / \mathrm{l}$ baikuntuk pertumbuhan organisme dan $>3,5$ $\mathrm{mg} / \mathrm{l}$ dapat membahayakan perairan. Berdasarkan PP No. 82 Tahun 2001, kandungan $\mathrm{NO}_{3}$ bagi ikan yaitu 10 - $20 \mathrm{mg} / \mathrm{l}$. Nitrat merupakan sumber nitrogen bagi tumbuhan yang selanjutnya dikonversi menjadi protein (Effendi, 2003). Untuk kadar nitrat-nitrogen pada perairan alami hampir tidak pernah melebihi dari $0,1 \mathrm{mg} / \mathrm{l}$, bila kadar nitrat lebih dari $5 \mathrm{mg} / \mathrm{l}$ menggambarkan terjadinya pecemaran yang berasal dari aktifitas manusia dan 
tinja hewan. Kadar nitrat untuk keperluan air minum sebaiknya tidak melebihi $10 \mathrm{mg} / \mathrm{l}$ (Davis dan Cornwell dalam Effendi, 2003).

Nitrat adalah bentuk utama nitrogen di perairan alami dan merupakan nutrien utama bagi pertumbuhan tanaman dan algae. Tanaman air dan fitoplankton lebih mudah menggunakan nitrogen dalam bentuk nitrat, maka semua nitrogen baru tersedia jika telah dalam bentuk nitrat. Pembentukan nitrat sangat tergantung pada adanya oksigen dalam proses oksidasi oleh bakteri Nitrobacter yang bertugas mengubah nitrit menjadi nitrat secara aerob (Isnaini, 2011). Konsentrasi oksigen terlarut yang sangat rendah dapat mengakibatkan terjadinya proses denitrifikasi, yaitu perubahan nitrat melalui nitrit yang akan menghantarkan nitrogen bebas yang akhirnya akan lepas ke udara atau kembali membentuk ammonium melalui proses ammonium nitrat. Parameter nitrat sangat penting untuk mengetahui kemampuan self purification suatu perairan dan untuk mengetahui keseimbangan unsur hara di air permukaan dan tanah (HH Rump dan H. Krist, 1992). Ditinjau dari kadar nitrat yang merupakan salah satu indikator kesuburan, maka perairan sungai Desa Ulak Jermun (stasiun 1), Desa Terusan Menang (stasiun 2), dan Desa Mangun Jaya (stasiun 3) baik untuk kegiatan budidaya perikanan system KJA yang berkisar $0.37-0.439$ mg/l.

\section{Fosfat $\left(\mathrm{PO}_{4}\right)$}

Fosfat merupakan nutrisi yang paling penting dalam menentukan produktivitas perairan. Keberadaan fosfat diserap oleh bakteri, phytoplankton dan makrofita. Fosfat seperti juga nitrogen dan sulfur, turut serta dalam daur geologis dunia. Dalam daur yang kecil, bahan organik yang mengandung fosfat (misalnya, sisa tumbuhan dan kotoran hewan) jadi busuk dan fosfat menjadi tersedia untuk diambil oleh akar tumbuhan dan penggabungan hasil menjadi bahan organik. Setelah melalui rantai makanan, sekali lagi melalui pengurai dan daur itu tertutup.

Air mengikis fosfat tidak hanya dari batuan yang mengandung fosfat tetapi juga dari tanah. Kandungan rata-rata nilai fosfat untuk dari pengambilan sampel berkisar $0.009-0.225 \mathrm{mg} / \mathrm{L}$ di Desa Ulak Jermun (stasiun 1), Desa Terusan Menang (stasiun 2), dan Desa Mangun Jaya (stasiun 3). Berdasarkan Peraturan Pemerintah No. 82 Tahun 2001 tentang baku mutu air nilai total fosfat berkisar sebesar 0,2-1 $\mathrm{mg} / \mathrm{l}$. Berdasarkan nilai fosfat yang didapat menyatakan bahwa masih baik untuk dikembangkan kegiatan budidaya system KJA.

Menurut Boyd dalam Effendi (2003), menyatakan fosfor pada perairan alami jarang melebihi $1 \mathrm{mg} / \mathrm{l}$. Tingginya nilai fosfat bisa disebabkan pemanfaatan sungai sebagai MCK oleh masyarakat yang beraktifitas di sekitar sungai dan berasal dari penggunaan pupuk dari aktifitas pertanian dan perkebunan yang berada dekat dengan pinggiran sungai dan diduga terjadi akibat dari akumulasi sisa pakan yang terbuang, feses dan ikan yang mati dari aktifitas budidaya ikan. Menurut Effendi (2003), fosfat tidak bersifat toksik bagi manusia, hewan dan ikan. Keberadaan fosfat di perairan sangat penting terutama berfungsi dalam pembentukan protein dan metabolisme bagi organisme. Namun tingginya fosfat dikhawatirkan menyebabkan terjadinya eutrofikasi berupa ledakan jumlah Algae (blooming) yang berakibat buruk bagi budidaya.

\section{KESIMPULAN DAN SARAN}

\section{Kesimpulan}

a. Berdasarkan Hasil penghitungan kesesuaian lahan dengan metode pembobotan menunjukkan kesesuaian lahan yang ada di sungai Komering Desa Serdang Menang kabupaten OKI Sumatera Selatan.

b. Dari hasil pengukuran parameter kualitas air didapat $\mathrm{pH}$ kisaran 6.6 - 6.7, suhu berkisar $24 ., 53-26.93^{\circ} \mathrm{C}$, DO 3.93 - $4.36 \mathrm{mg} / \mathrm{l}$, ammonia $0.78-0,16 \mathrm{mg} / \mathrm{l}$, kecerahan perairan berkisar $34.67-43.33 \mathrm{~cm}, \mathrm{CO}_{2} 4.53$ - 5.03 $\mathrm{mg} / \mathrm{l}$, kedalaman $2.36-2.47 \mathrm{~m}$, kecepatan arus $0.38-0.44 \mathrm{~m} / \mathrm{s}$, nitrat $0.37-0.439 \mathrm{mg} / \mathrm{l}$, fosfat $0.009-0.225 \mathrm{mg} / \mathrm{l}$ dan subtrat dasar perairan adalah lumpur.

\section{Saran}

Pengelolaan perairan sungai komering harus memperhatikan dan menjaga kualitas perairan karena limbah yang dikeluarkan agar tidak mencemari lingkungan.

\section{UCAPAN TERIMA KASIH}

1. Kementrian RISTEKDIKTI atas dana yang diberikan untuk penelitian ini.

2. KOPERTIS Wilayah II

3. RektorUniversitas PGRI Palembang

4. Dekan Fakultas Perikanan

5. Ketua LPPKMK Universitas PGRI Palembang

6. Semua pihak yang telah membantu dalam pelaksanaan kegiatan penelitian ini

\section{DAFTAR PUSTAKA}

Affan, J.M. 2012. Identifikasi Lokasiuntuk Pengembangan Budidaya Keramba Jaring Apung Berdasarkan Faktor Lingkungan dan Kualitas Airdi Perairan Pantai Timur Bangka Tengah. Depik 1(1): 78-85.

Boyd, C.E. 1983. Water Quality in Warm Water Fish Pond. Auburn University Agricultural. Entertaiment. Auburn 
BPS OKI. 2015. Luas wilayah menurut Kecamatan di Kabupaten Ogan Komering Ilir. Badan Pusat Statistik Kabupaten Ogan Komering Ilir.

Effendi, H. 2003. Telaah Kualitas Air bagi Pengelolaan Sumberdaya dan Lingkungan Perairan. Kanisius, Yogyakarta.

Ervinia, A. 2011. Keadaan Amonia Pasca Aerasi Hipolimnion di Danau Lido Bogor Jawa Barat. [Skripsi]. InstitutPertanian Bogor, Bogor.

Haris, R.B.K, Nurbambang, A dan Anggoro, S. 2017. Analisis Prospek Pengembangan Usaha Pembesaran Ikan Bandeng (Chanos chanos Forskal 1775) di Kecamatan Tugu Kota Semarang Provinsi Jawa Tengah. Jurnal Ilmiah AgrIBA Vol. 5 (1) : 70 - 83

Isnaini, A. 2011. Penilaian kualitas air dan kajian potensi situ salam sebagai wisata air di Universitas Indonesia. Jakarta

Peraturan Pemerintah. 2001. Peraturan Pemerintah Republik Indoneria Nomor 82 Tahun 2001. Tentang Pengelolaan Kualitas Air dan Pengendalian Pencemaran Air.

Praptokardyo, K dan W. Muskita. 2008. Pengembangan Perikanan Budidaya. Sekolah Tinggi Perikanan Jurusan Penyuluhan Perikanan. Bogor.
Samuel dan Adjie, S. 2008. Zonasi, Karakteristik Fisik-Kimia air dan Jenis-jenis ikan yang Tertangkap di Sungai Musi, Sumatera Selatan. Jurnal Ilmu-ilmu Perairan dan Perikanan Indonesia, 15 (1): 41-48.

Sari, K. Y. 2011.Analisis Spasial Citra Satelit Landsat untuk Penetuan Lokasi Budidaya Keramba Jaring Apung Ikan Kerapu di Perairan Pulau Semujur Kabupaten Bangka Tengah. Institut Pertanian Bogor. Bogor.

Sastrawijaya. 2000. Pencemaran Lingkungan. Cetakan Ke-2. Penerbit PT Rineka Cipta. Jakarta.

Wardoyo, S.T.H. 1982. Water Analisys Manual Tropical Aquatic Biology, Bogor.

Wiadnyana N.N., Husnah dan Gaffar, A.K. 2011. Perikanan dan Kondisi Lingkungan Sumberdaya Ikan Perairan Umum Daratan Riau. Balai Penelitian Perikanan Perairan Umum.Pusat Penelitian dan Konservasi Sumber Daya Ikan. Badan Penelitian dan Pengembangan Kelautan dan Perikanan. Kementrian Kelautan dan Perikanan. 